\title{
ANALISIS POLA KEPUASAN PENGUNJUNG TERHADAP DAYA TARIK WISATA TAMAN SARI YOGYAKARTA DENGAN IMPORTANCE PERFORMANCE ANALYSIS (IPA)
}

\author{
Novi Irawati \\ Sekolah Tinggi Pariwisata Ambarrukmo (STIPRAM), Yogyakarta \\ e-mail : irawati_novie@yahoo.co.id \\ Sri Wahyuni \\ Sekolah Tinggi Pariwisata Ambarrukmo (STIPRAM), Yogyakarta \\ e-mail : yiyieid@yahoo.com
}

\begin{abstract}
Visitor Satisfaction is a comparison between the performance expected by the customer compared to the actual performance in the field. When actual performance is higher than customer expectations, the customer feels satisfied and vice versa. The purpose of this study is to determine the performance of managers in providing good service to tourists and measuring customer satisfaction to the services provided while in Taman Sari Yogyakarta Tourism Object, by knowing the quality of performance of officers or managers in providing services to tourists are expected to be able to make improvements and evaluation of the management of servants so that the object of Taman Sari Cultural Tourism can be a tourist attraction that is in demand by tourists not only because of its tourist attraction but because of the quality of the servants who are good to tourists.
\end{abstract}

\begin{abstract}
ABSTRAK
Kepuasan Pengunjung adalah Perbandingan antara kinerja yang diharapkan oleh pelanggan dibandingkan dengan kinerja aktual di lapangan. Ketika kinerja aktual lebih tinggi dibandingkan dengan harapan pelanggan maka pelanggan merasakan puas dan sebaliknya. Tujuan dari penelitian ini adalah untuk mengetahui kinerja dari pengelola dalam memberikan pelayanan yang baik kepada wisatawan dan mengukur kepuasaan pelanggan terhadapat pelayanan yang diberikan selama berada di Objek Wisata Taman Sari Yogykarta, dengan mengetahui kualitas kinerja petugas atau pengelola dalam memberikan pelayanan kepada wisatawan diharapkan mampu melakukan pembenahan dan evaluasi terhadap management pelayan sehinggan Objek Wisata Budaya Taman Sari dapat menjadi objek wisata yang diminati oleh wisatawan bukan hanya karena objek wisata nya melainkan karena kualitas pelayan yang baik kepada wisatawan.
\end{abstract}

Kata Kunci : kualitas pelayanan, importance performance analysis, kepuasan pelanggan

\section{PENDAHULUAN}

Pariwisata saat ini merupakan salah satu hal penting dalam suatu negara untuk menyokong perekonomian dan meningkatkan devisa. Pariwisata kian berkembang dari waktu ke waktu seiring dengan perkembangan zaman.
Perkembangan itu berdampak pada keberagaman jenis pariwisata yang ada saat ini, mulai dari wisata alam, budaya, sejarah, heritage, seni, dll. Salah satu jenis pariwisata yang kian populer adalah wisata heritage. Wisata heritage adalah sebuah 
perjalanan wisata menuju tempat-tempat warisan sejarah pada maa lampau, salah satu tempat wisata heritage yang cukup terkenal adalah Taman Sari. Taman Sari adalah situs budaya yang yang dulunya berupa tempat pemandian dan kebun istana Keraton Ngayogyakarta Hadiningrat, Taman Sari dibangun pada pemerintahan Sri Sultan Hamengku Buwono I pada tahun 1758-1765. Terletak tidak terlalu jauh dari Keraton Yogyakarta menjadikan tempat wisata ini cukup ramai pengunjung. Objek wisata Taman Sari mulai dikenal masyarakat luas pada sekitar tahun 2010an siring dengan berkembangnya sosial media sehingga sangat memudahkan siapapun untuk mengakses tempat ini secara online. Karena hal itulah yang membuat Taman Sari sangatlah populer bagi wisatawan yang mengunjungi Yogyakarta dan hal itu berdampak pada membludaknya kunjungan wisatawan di objek wisata ini. Pada saat awal-awal terkenalnya, pengelolaan tempat wisata ini masih kurang baik walaupun pada saat ini juga masih beberapa hal yang harus diperbaiki, masala-masalah yang timbul kebanyakan bersumber pada beberapa aspek seperti kebersihan, kenyamanan, keamanan dan kurangnya fasilitas penunjang para wisatawan untuk berwisata. Contohnya seperti kurangnya papan informasi mengenai Taman Sari, minimnya toilet, dan rute antar antraksi yang membingungkan karena tidak tersedianya papan penunjuk arah. Hal itulah yang sering dikeluhkan oleh wisatawan sehingga menguragi rasa kenyamanan saat berwisata. Oleh karena itulah diperlukan sebuah pengelolaan yang lebih baik dalam menjalankan sebuah usaha pariwisata unggulan dan masalah-masalah tersebut yang mendorong kami untuk melakukan sebuah penelitaian mengenai kepuasan pengunjung untuk meningkatkan kualitas pelayanan melalui metode Total Quality Management. TQM atau Total Quality Management adalah sebuah strategi dalam manajemen yang ditujukan untuk menanamkan kesadaran kualitas pada semua proses dalam organisasi, dalam kata lain TQM adalah sebuah pendekatan manajemen pada sebuah organisasi yang menitikberatkan pada kualitas berdasarkan partisipasi anggotanya yang berfokus pada pelanggan yang dilakukan melalui evaluasi dan perbaikan yang berkesinambungan untuk mencapai keberhasilan jangka panjang melalui kepuasan pelanggan. Dalam TQM diperlukan strategi, data, dan komunikasi yang efektif untuk mengintegrasikan kedisiplinan kualitas dalam budaya dan kegiatan-kegiatan pengelola. Data yang kami peroleh kemudian akan dianalisis menggunakan metode IPA (Importance Peformance Analysis) yang diukur melalui presepsi/ekspektasi konsumen dan prioritas peningkatan kualitas produk/jasa yang dikenal sebagai quadrant analysis

\section{STUDI PUSTAKA}

\section{Total Quality Management (TQM)}

Total Quality Management secara harfiah berasal dari kata "total" yang berarti keseluruhan atau terpadu, "quality" yang berarti kualitas, dan "management" telah disamakan dengan manajemen dalam bahasa Indonesia yang diartikan dengan pengelolaan. Jadi dari asal katanya "Total Quality Management" dapat diartikan manajemen mutu terpadu atau manajemen kualitas terpadu.

Pengertian Total Quality Management (TQM) menurut International Organization for Standarizasion (IOS) dalam Kurniawaty (2012) : TQM adalah pendekatan manajemen pada suatu organisasi, berpusat pada kualitas, berdasarkan partisipasi semua anggotanya dan bertujuan untuk kesuksesan jangka panjang melalui kepuasan pelanggan, dan manfaat bagi semua anggota organisasi dan masyarakat.Total Quality Management/Manajemen Mutu.

Kualitas merupakan paradigma baru dalam menjalankan bisnis yang berorientasi pada 
pelanggan dan berupaya memaksimumkan daya saing organisasi melalui perubahan/ perbaikan manajemen secara terusmenerus dan berkesinambungan terhadap proses, kualitas produk,jasa, dan lingkungan organisasi.

\section{Importance Performance Analysis (IPA)}

Importance Performance Analysis, menurut Tjiptono (2011) teknik ini dikemukakan pertama kali oleh Martilla dan James pada tahun 1977 dalam artikel mereka "Importance-Performance Analysis" yang dipublikasikan di Journal of Marketing. Pada teknik ini, responden diminta untuk menilai tingkat kepentingan dan kinerja pengelola, kemudian nilai ratarata tingkat kepentingan dan kinerja tersebut dianalisis pada ImportancePerformance Matrix, yang mana sumbu $\mathrm{x}$ mewakili persepsi sedangkan sumbu $\mathrm{y}$ mewakili harapan. Maka nanti akan didapat hasil berupa empat kuadran sesuai gambar 1 berikut:

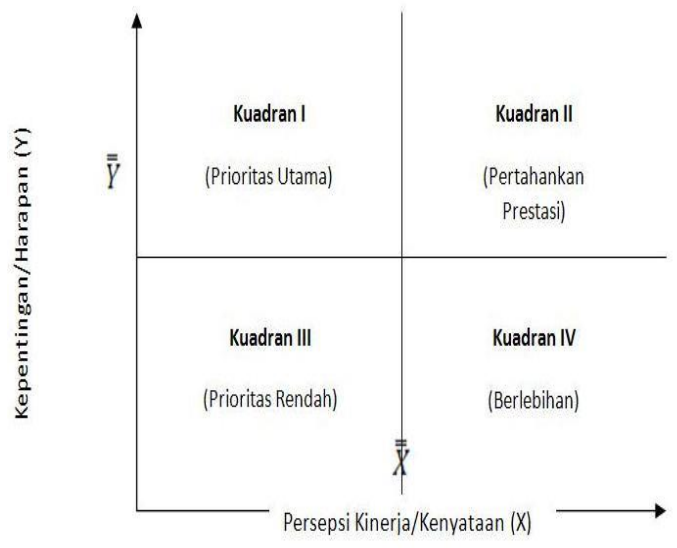

Gambar 1. Kuadran Persepsi Tingkat Kepentingan dan Kinerja

Adapun interpretasi dari kuadran tersebuat adalah sebagai berikut:

a. Prioritas Utama (Concentrate
Here)

Pada kuadaran ini terdapat faktorfaktor yang dianggap penting dan atau diharapkan konsumen akan tetapi kinerja pengelola dinilai belum memuaskan sehingga pihak pengelola perlu berkonsentrasi untuk mengalokasikan sumber dayanya guna meningkatkan performa yang masuk pada kuadran ini.

b. Pertahankan Prestasi (Keep Up The Good Work)

Pada kuadaran ini terdapat faktorfaktor yang dianggap penting dan diharapkan sebagai faktor penunjang kepuasan konsumen sehingga pengelola wajib untuk mempertahankan prestasi kinerja tersebut.

c. Prioritas Rendah (Low Priority) Pada kuadaran ini terdapat faktorfaktor yang dianggap mempunyai tingkat persepsi atau kinerja aktual yang rendah dan tidak terlalu penting dan atau tidak terlalu diharapkan oleh konsumen sehingga pengelola tidakperlu memprioritaskan atau memberikan perhatian lebih pada faktor-faktor tersebut.

d. Berlebihan (Possibly Overkill)

Pada kuadaran ini terdapat faktorfaktor yang dianggap tidak terlalu penting dan tidak terlalu diharapkan oleh pelanggan sehingga pengelola lebih baik mengalokasikan sumber daya yang terkait pada faktor tersebut kepada factor lain yang lebih memiliki tingkat prioritas lebih tinggi.

\section{Skala Likert}

Dalam menentukan hasil dari Importance Performance Analysis, penelitian ini juga menggunakan teknik Skala Likert. Sugiyono (2012) menerangkan bahwa skala Likert digunakan untuk mengukur sikap atau pendapat seseorang atau sejumlah kelompok terhadap sebuah fenomena sosial yang dimana jawaban setiap item instrumen mempunyaigradasi dari sangat positif sampai sangat negatif. Dengan skala likert variabel yang akan diukur dijabarkan menjadi indikator variabel. Kemudian indikator tersebut dijadikan titik tolak untuk menyusun item- 
item instrumen yang dapat berupa pernyataan atau pertanyaan. Berikut adalah skala yang dipakai pada penelitian ini:
a. Setuju
b. Cukup Setuju
c. Setuju
d. Tidak Setuju
e. Sangat tidak setuju

Skala Likert merupakan metoda skala bipolar yang mengukur baik tanggapan

\section{METODE}

Penelitian ini akan diawali dengan analisis kinerja perusahaan dengan menggunakan pendekatan kualitatif, dimana dengan pendekatan ini peneliti berusaha untuk memahami analisis kualitas mutu penerapan TQM.

Menurut Sutopo (2006) sebelum merancang pelaksanaan penelitian, perlu dipahami bahwa terdapat dua jenis penelitian, yang dibedakan dari tujuan akhirnya. Data kualitatif yang dikumpulkan terutama berupa kata-kata, kalimat atau gambar yang memiliki arti lebih bermakna dan mampu memacu pemahaman yang lebih nyata daripada sekedar sajian angka atau frekuensi (Sutopo, 2006). Atas dasar bentuk penelitain tersebut, maka penelitian dilakukan dengan tiga tahap, yaitu tahap orientasi, tahap eksplorasi, dan tahap member check. Adapun strategi yang digunakan adalah studi kasus terpancang tunggal. Dikatakan studi kasus tunggal karena memfokuskan pada kasus yaitu kepuasan pengunjung pada obyek wisata Taman Sari. Adapun rincian metode yang akan digunakan adalah sebagai berikut:

\section{Lokasi dan Jenis Penelitian}

Penelitian ini dilaksanakan di Kawasan Wisata Taman Sari Yogyakarta, dengan pertimbangan bahwa: pengelola ini sedang melakukan upaya penerapan Total Quality Management (TQM) guna memenuhi standar pengelola. Kondisi tersebut menarik untuk diteliti positif ataupun negatif terhadap suatu pernyataan. Empat skala pilihan juga kadang digunakan untuk kuesioner skala Likert yang memaksa orang memilih salah satu kutub karena pilihan "netral" tak tersedia. Likert, Rensis (1932), "A Technique for the Measurement of Attitudes", Archives of Psychology 140: 155.

mengingat penerapan Total Quality Management (TQM) secara konsep dinyatakan dapat berpengaruh terhadap peningkatan kualitas sumber daya manusia sehingga dapat membantu pengelola dalam melakukan perencanaan dalam melakukan perencanaan kualitas dengan lebih baik.

\section{Jenis Data dan Sumber Data}

Jenis data yang digunakan dalam penelitian ini yaitu data kualitatif dan data ata kualitatif yaitu merupakan data yang berupa uraian atau kalimat yaitu mengenai sejarah pengelola dan proses produksi sedangkan data kuantitatif yaitu data berupa angka yaitu mengenai skor hasil penyebaran kuesioner.

\section{Populasi dan Sampel}

Populasi dan sampel Populasi yang akan diteliti adalah pengunjung dan pengelola. Pengunjung dipilih yang berusia antara 15- 60 tahun dengan anggapan bahwa usia tersebut merupakan usia yang bisa diandalkan dalam pengisian kuesioner. Sampel diambil secara acak terhadadap pengunjung, dan para pengelola Taman Sari. Jumlah sampel yang berhasil dikumpulkan adalah 25 sampel terdiri dari 5 sampel dari staf/karyawan Taman Sari dan 20 sampel dari pengunjung.

\section{Teknik Pengumpulan Data}


Adapun teknik pengumpulan datanya dilakukan dengan cara sebagai berikut.

a. Metode Observasi

Observasi adalah suatu cara pengumpulan data dengan pengamatan langsung dan pencatatan secara sistematis terhadap obyek yang akan diteliti. Observasi dilakukan oleh peneliti dengan cara pengamatan dan pencatatan mengenai pelaksanaan pembelajaran dikelas.

b. Kuesioner

Kuesioner merupakan sejumlah pertanyaan tertulis yang digunakanuntuk memperoleh sejumlah informasi dari responden yang berisi laporan tentang pribadinya, atau hal lain yang diketahui. Kuesioner digunakan untuk mengumpulkan data tentang persepsi dan harapan dari wisatawan dan juga pengelola dai taman sari

c. Dokumentasi

Dokumentasi berupa foto-foto kegiatan pelaksanaan penelitian di Taman Sari

Adapun kerangka dari penelitian ini dapat dilihat pada Gambar 2 berikut ini:

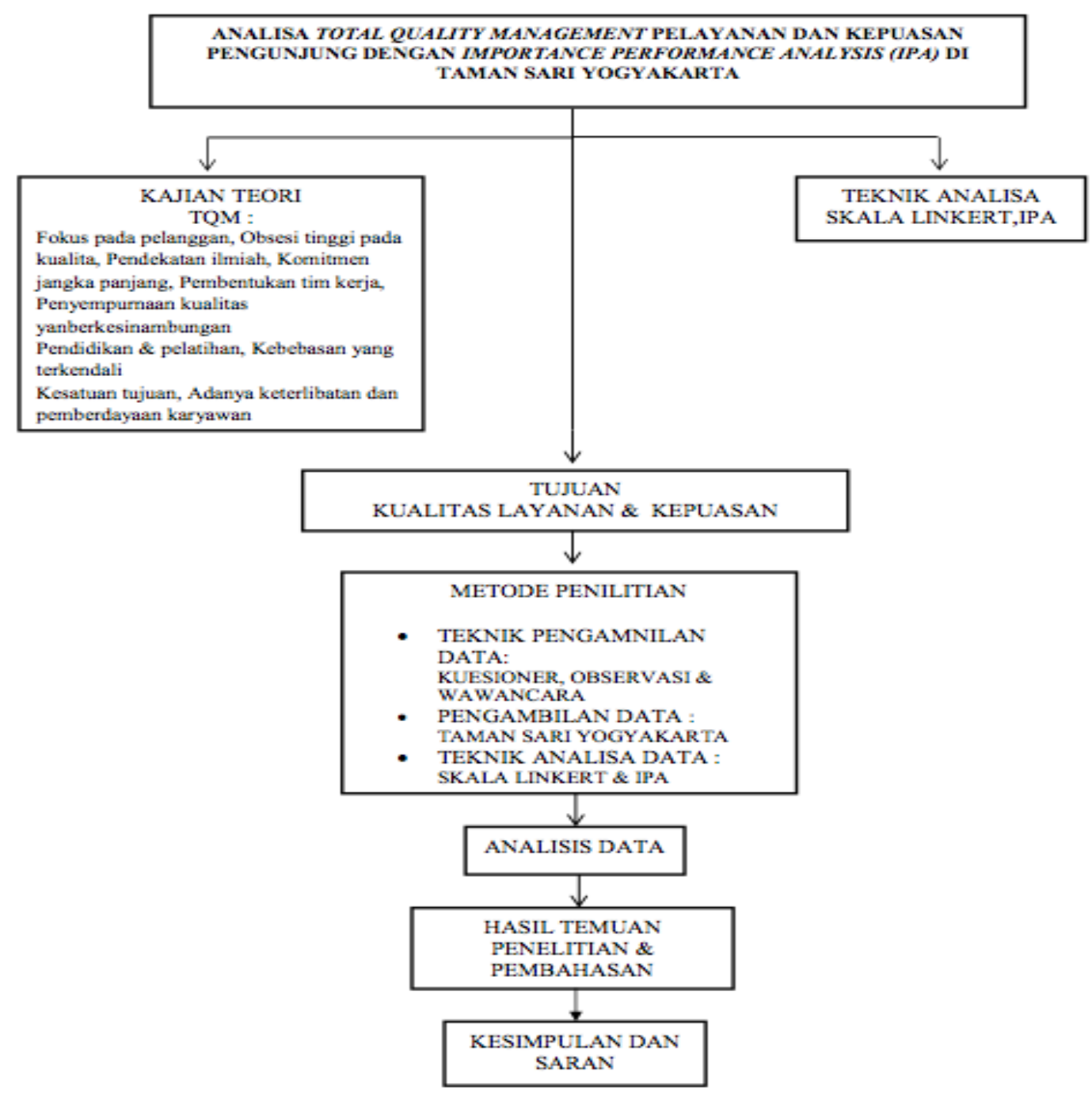

Gambar 2. Kerangka Penelitian 


\section{ANALISIS DAN PEMBAHASAN}

Kualitas adalah kemampuan dari suatu produk baik barang maupun jasa dalam memenuhi kebutuhan konsumen, di mana produk yang berkualitas akan memberikan kepuasan, sehingga kepercayaan untuk mengkonsumsi produk tersebut akan terus dijadikan loyalitas konsumen terhadap produk tersebut adapun cara unutk mencapainya diantaranya Fokus pada pelanggan Obsesi tinggi pada kualitas, Pendekatan ilmiah, Komitmen jangka panjang, Pembentukan tim kerja, Penyempurnaan kualitas yang berkesinambungan, Pendidikan \& pelatihan, Kebebasan yang terkendali, Kesatuan tujuan, Adanya keterlibatan dan pemberdayaan karyawan. Untuk itu, variabel dan indikator kepada wisatawan dapat dilihat pada tabel 1 dan hasil dari skor kepuasan wisatawan terhadap kualitas pelayanan di Taman Sari dapat dilihat pada tabel 2, serta Skor Kinerja Pengelola Terhadap Kualitas Pelayanan di Taman Sari ddapat dilihat pada tabel 3 berikut: 
Tabel 1. Variabel dan Indikator Wisatawan

\begin{tabular}{|c|c|c|c|}
\hline \multicolumn{4}{|c|}{ Variabel dan Indikator Penelitian Kepada Wisatawan } \\
\hline No & Variable & Indikator & Deskriptor \\
\hline \multirow[t]{13}{*}{1} & $\begin{array}{c}\text { Fokus } \\
\text { pada }\end{array}$ & $\begin{array}{c}\text { Serviceabilit } \\
\mathrm{y}\end{array}$ & $\begin{array}{l}\text { a. Penempatan ATM mudah dijangkau oleh } \\
\text { wisatawan }\end{array}$ \\
\hline & Pelangga & & \\
\hline & $\mathrm{n}$ & & \\
\hline & & & $\begin{array}{l}\text { b. Lahan parkir yang disediakan pihak Taman Sari } \\
\text { sudah cukup luas }\end{array}$ \\
\hline & & & $\begin{array}{l}\text { c. Keamanan wisatawan sudah terjamin selama } \\
\text { mengunjungi Taman Sari }\end{array}$ \\
\hline & & & $\begin{array}{l}\text { d. Tersedianya papan informasi yang cukup untuk } \\
\text { memberi informasi kepada wisatawan }\end{array}$ \\
\hline & & & e. PKL di Taman Sari sudah sangat mudah \\
\hline & & & f. Ketersediaan pemandu wisata sudah cukup memadai \\
\hline & & & $\begin{array}{l}\text { g. Wisatawan bingung dengan rute perjalanan di } \\
\text { dalam Taman Sari }\end{array}$ \\
\hline & & & h. Petugas Taman Sari ramah kepada wisatawan \\
\hline & & & $\begin{array}{l}\text { i. Petugas Taman sari dapat menindaklanjuti keluhan } \\
\text { dari wisatawan dengan cepat dan baik }\end{array}$ \\
\hline & & & j. Lingkungan Taman Sari sangat bersih \\
\hline & & & $\begin{array}{l}\text { k. Petugas mampu berkomunikasi yang baik dengan } \\
\text { pengunjung. }\end{array}$ \\
\hline \multirow[t]{9}{*}{2.} & Obsesi & Sudut & a. Pemeliharaan kawasan Taman Sari sudah dilakukan \\
\hline & Tinggi & Pandang & dengan baik \\
\hline & pada & Pelanggan & \\
\hline & Kualitas & & \\
\hline & & & $\begin{array}{l}\text { b. Penanganan sampah dan kebersihan di Taman Sari } \\
\text { sudah sangat baik }\end{array}$ \\
\hline & & & $\begin{array}{l}\text { c. Wisatawan nyaman dan dapat menikmati objek } \\
\text { wisata taman sari }\end{array}$ \\
\hline & & & d. Akses menuju taman sari sudah sangat mudah \\
\hline & & & $\begin{array}{l}\text { e. Wisatawan puas dengan kualitas pelayanan di } \\
\text { Taman Sari }\end{array}$ \\
\hline & & & $\begin{array}{l}\text { f. Wisatawan puas dengan kualitas Guide dari di } \\
\text { Taman Sari }\end{array}$ \\
\hline \multirow[t]{4}{*}{3.} & Komitme & Perbaikan & a. Pengelola telah menjaga nilai kebudayaan yang ada \\
\hline & n Jangka & Kualitas & di taman sari \\
\hline & Panjang & Budaya & \\
\hline & & & $\begin{array}{l}\text { b. Pengelola telah mengembangkan nilai kebudayaan } \\
\text { yang ada di taman sari }\end{array}$ \\
\hline
\end{tabular}


Tabel 2. Skor Kepuasaan Wisatawan Terhadap Kualitas Pelayanan di Taman Sari

\begin{tabular}{|c|l|c|c|c|}
\hline \multirow{2}{*}{ No } & \multicolumn{1}{|c|}{ Deskriptor } & \multicolumn{2}{c|}{ Skor } & Skor \\
\cline { 3 - 5 } & & Presepsi & Ekspektasi & Kepuasaan \\
\hline 1 & Penempatan ATM mudah dijangkau oleh wisatawan & 2,15 & 3 & $-0,85$ \\
\hline 2 & $\begin{array}{l}\text { Lahan parkir yang disediakan pihak Taman Sari sudah } \\
\text { cukup luas }\end{array}$ & 3,9 & 4 & $-0,1$ \\
\hline \multirow{2}{*}{3} & $\begin{array}{l}\text { Keamanan wisatawan sudah terjamin selama } \\
\text { mengunjungi Taman Sari }\end{array}$ & 3,1 & 3,5 & $-0,4$ \\
\hline \multirow{2}{*}{4} & $\begin{array}{l}\text { Tersedianya papan informasi yang cukup untuk } \\
\text { memberi informasi kepada wisatawan }\end{array}$ & 3,65 & 4 & $-0,35$ \\
\hline 5 & PKL di Taman Sari sudah sangat mudah & 3,75 & 5 & $-1,25$ \\
\hline 6 & Ketersediaan pemandu wisata sudah cukup memadai & 3,75 & 4 & $-0,25$ \\
\hline 7 & $\begin{array}{l}\text { Wisatawan paham dengan rute perjalanan di dalam } \\
\text { kawasan Taman Sari }\end{array}$ & 2,2 & 4 & $-1,8$ \\
\hline 8 & Petugas Taman Sari ramah kepada wisatawan & 3,25 & 4 & $-0,75$ \\
\hline \multirow{2}{*}{9} & $\begin{array}{l}\text { Petugas Taman sari dapat menindaklanjuti keluhan dari } \\
\text { wisatawan dengan cepat dan baik }\end{array}$ & 3,3 & 3,5 & $-0,2$ \\
\hline 10 & Lingkungan Taman Sari bersih & 3,45 & 4 & $-0,55$ \\
\hline \multirow{2}{*}{11} & $\begin{array}{l}\text { Petugas mampu berkomunikasi yang baik dengan } \\
\text { pengunjung. }\end{array}$ & 3,7 & 4 & $-0,3$ \\
\hline \multirow{2}{*}{12} & $\begin{array}{l}\text { Pemeliharaan kawasan Taman Sari sudah dilakukan } \\
\text { dengan baik }\end{array}$ & 3,6 & 4 & $-0,4$ \\
\hline \multirow{2}{*}{13} & $\begin{array}{l}\text { Penanganan sampah dan kebersihan di Taman Sari } \\
\text { sudah sangat baik }\end{array}$ & 3,4 & 4 & $-0,6$ \\
\hline \multirow{2}{*}{14} & $\begin{array}{l}\text { Wisatawan nyaman dan dapat menikmati objek wisata } \\
\text { taman sari }\end{array}$ & 3,9 & 5 & $-1,1$ \\
\hline 15 & Akses menuju taman sari sudah sangat mudah & 3,85 & 4 & $-0,15$ \\
\hline \multirow{2}{*}{16} & $\begin{array}{l}\text { Wisatawan puas dengan kualitas pelayanan di Taman } \\
\text { Sari }\end{array}$ & 3,65 & 4 & $-0,35$ \\
\hline 17 & Wisatawan puas dengan fasilitas dari di Taman Sari & 3,8 & 4 & $-0,2$ \\
\hline \multirow{2}{*}{18} & $\begin{array}{l}\text { Pengelola telah menjaga nilai kebudayaan yang ada di } \\
\text { taman sari }\end{array}$ & 3,95 & 4 & $-0,05$ \\
\hline \multirow{2}{*}{19} & $\begin{array}{l}\text { Pengelola telah mengembangkan nilai kebudayaan } \\
\text { yang ada di taman sari }\end{array}$ & 3,75 & 4 & $-0,25$ \\
\hline 20 & pengelola telah melsetarikan nilai budaya dengan baik & 3,8 & 4 & $-0,2$ \\
\hline & & & 4 & \\
\hline
\end{tabular}


Tabel 3. Skor Kinerja Pengelola Terhadap Kualitas Pelayanan di Taman Sari

Pengelola melayani wisatawan yang datang ke

1 loket karcis dengan baik

Pengelola mampu beriinteraksi dengan

2 wisatawan dengan baik

Pengelola mampu memberikan rasa aman dan

3 nyaman kepada wisatawan

Pengelola menyediakan Guide yang berkualitas

4 kepada wisatawan

Pengelola dapat menerima dan menyelesaikan

5 keluhan dari wisatawan dengan baik

Pengelola selalu memperhatikan kualitas

6 kebersihan di Taman sari

Pengelola menyediakan Parkir yang luas bagi

7 wisatawan

Pengelola selalu memberikan kualitas pelayanan

8 terbaik kepada wisatawan

Pengelola mampu memperbaiki kualitas

9 pelayanan kami yang buruk

Biaya Operasional dari pemerintah dalam

memelihara kawasan wisata taman sari sudah

10 mencukupi

Terdapat kerja sama yang baik antara pengelola

11 dengan masyarakat sekitar

Pengelola dapat menjaga nilai kebudayaan yang

12 ada di taman sari

Pengelola selalu melakukan evaluasi kualitas

13 pelayanan secara berkala

14 Pengelola melakukan pelatihan terhadap guide

Pengelola meningkatkan keterampilan dan

15 kemampuan karyawan

Pengelola telah melakukan promosi wisata taman

16 sari dengan baik

17 Koordinasi antar pegawai sudah baik

Pegawai mendapat jaminan asuransi dari

18 management taman sari

Pegawai mendapatkan fasilitas keamanan dan

19 keselamatan di tempat kerja.

Pegawai melakukan tugas sesuai dengan standard

20 yang telah ditetapkan

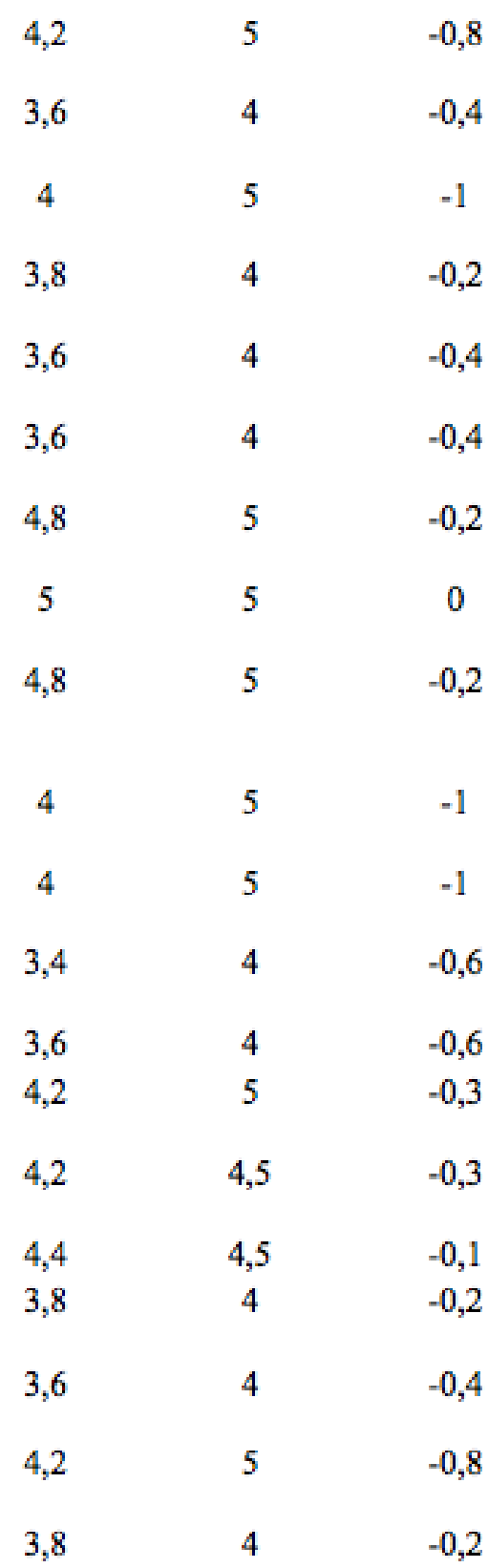

\section{Analisis Importance Performance}

Analysis (IPA)

Pada bagian ini dibahas mengenai pemetaan dari nilai kinerja (x) dan harapan (y), dari hasil tersebut maka akan terbentuk matriks yang terdiri dari empat buah kuadran yang masing-masing kuadran menggambarkan skala prioritas dalam mengambil kebijakan baik berupa peningkatan kinerja atau mempertahankan kinerja pengelola. Data sebaran kinerja dan harapan pelanggan dapat dilihat pada Gambar 3 


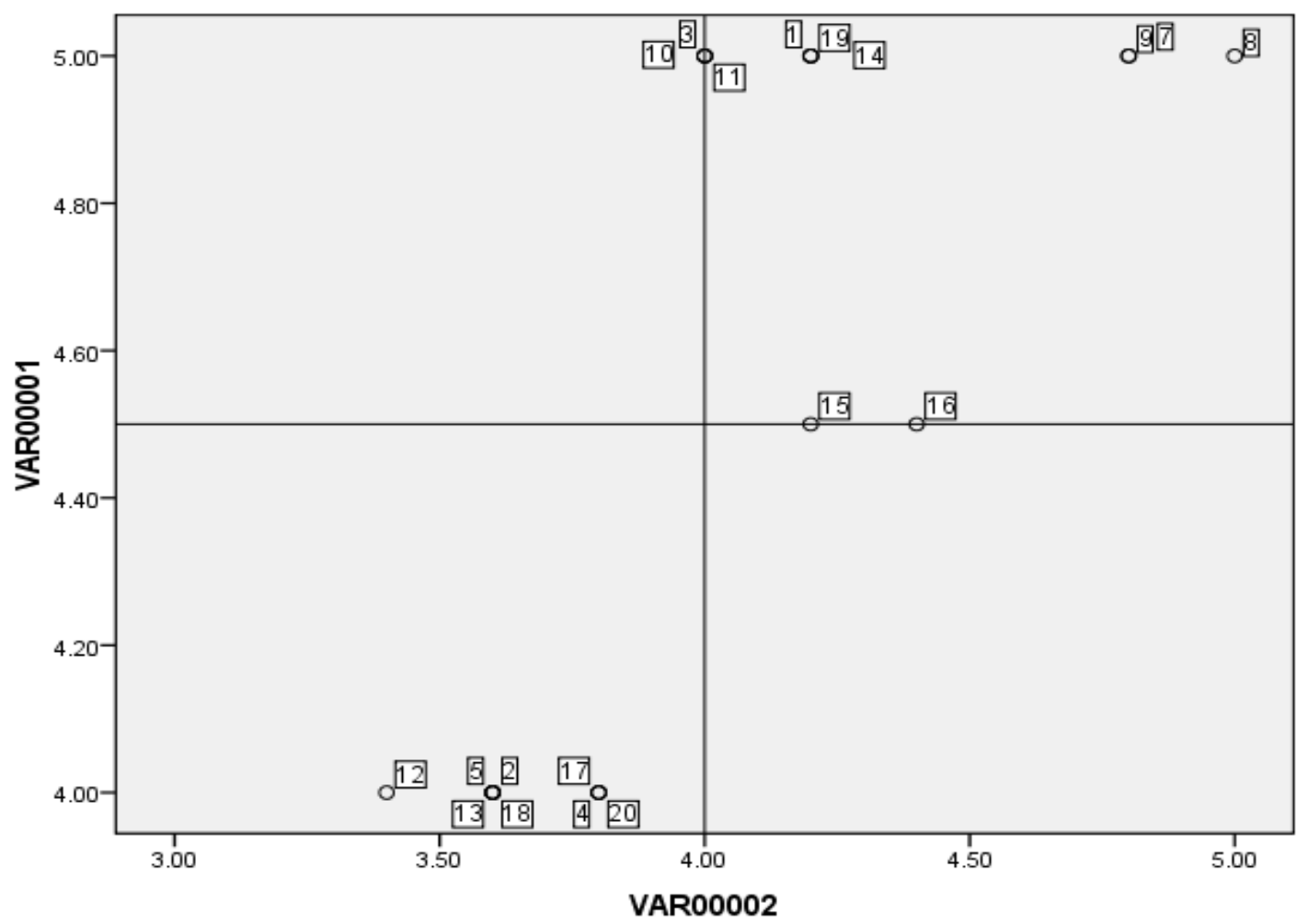

Gsmbsr 3. Diagram Kartesius Pengukuran Kinerja Pengelola

Keterangan : dibagian Kuadran C disana seharusnya terdapat case number 6 , Dari gambar di atas maka dapat di interpretasikan sebagai berikut

1. Kuadran A

Kuadran A menunjukan faktor atau atribut yang dianggap penting oleh wisatawan namun kondisi pada saat ini belum memuaskan, variable variable yang termasuk dalam kuadran ini adalah

(3) Pengelola mampu memberikan rasa aman dan nyaman kepada wisatawan

(10) Petugas Taman Sari ramah kepada wisatawan

Dengan demikian item ini menjadi skala prioritas yang harus di benahi oleh pengelola sebab item ini sangat penting bagi para wisatawan di Taman Sari

2. Kuadran $B$

Kuadran B menunjukan faktor atau atribut yang dianggap penting dan memuaskan wisatawan yang sudah dilaksanakan dengan baik oleh pengelola sehingga pihak manajemen Taman Sari berkewajiban memastikan bahwa kinerja yang dilakukan oleh para petugas/pengelola dapat terus mempertahankan prestasi yang sudah dicapai

Variable variable yang termasuk dalam kuadran ini adalah

(1) Pengelola melayani wisatawan yang datang ke loket karcis dengan baik

(9) Pengelola mampu memperbaiki kualitas pelayanan yang buruk

(7) Pengelola menyediakan Parkir yang luas bagi wisatawan

(11) Terdapat kerja sama yang baik antara pengelola dengan masyarakat sekitar

(8) Pengelola selalu memberikan kualitas pelayanan terbaik kepada wisatawan 
(19) Petugas mendapatkan fasilitas keamanan dan keselamatan di tempat kerja.

(15) Pengelola meningkatkan keterampilan dan kemampuan karyawan

(16) Pengelola telah melakukan promosi wisata taman sari dengan baik

(14) Pengelola melakukan pelatihan terhadap guide

3. Kuadran $\mathrm{C}$

Kuadran $\mathrm{C}$ menunjukan faktor yang dianggap kurang penting oleh pengelola dan tidak terlaksana dengan baik oleh pengelola

(12) Pengelola dapat menjaga nilai kebudayaan yang ada di taman sari

(6) Pengelola selalu memperhatikan kualitas kebersihan di Taman sari
(2) Pengelola mampu beriinteraksi dengan wisatawan dengan baik

(5) Pengelola dapat menerima dan menyelesaikan keluhan dari wisatawan dengan baik

(13) Pengelola selalu melakukan evaluasi kualitas pelayanan secara berkala

(4) Pengelola menyediakan Guide yang berkualitas kepada wisatawan

(20) Pegawai melakukan tugas sesuai dengan standard yang telah ditetapkan

(17) Koordinasi antar pegawai sudah baik

(18) Pegawai mendapat jaminan asuransi dari management taman sari 


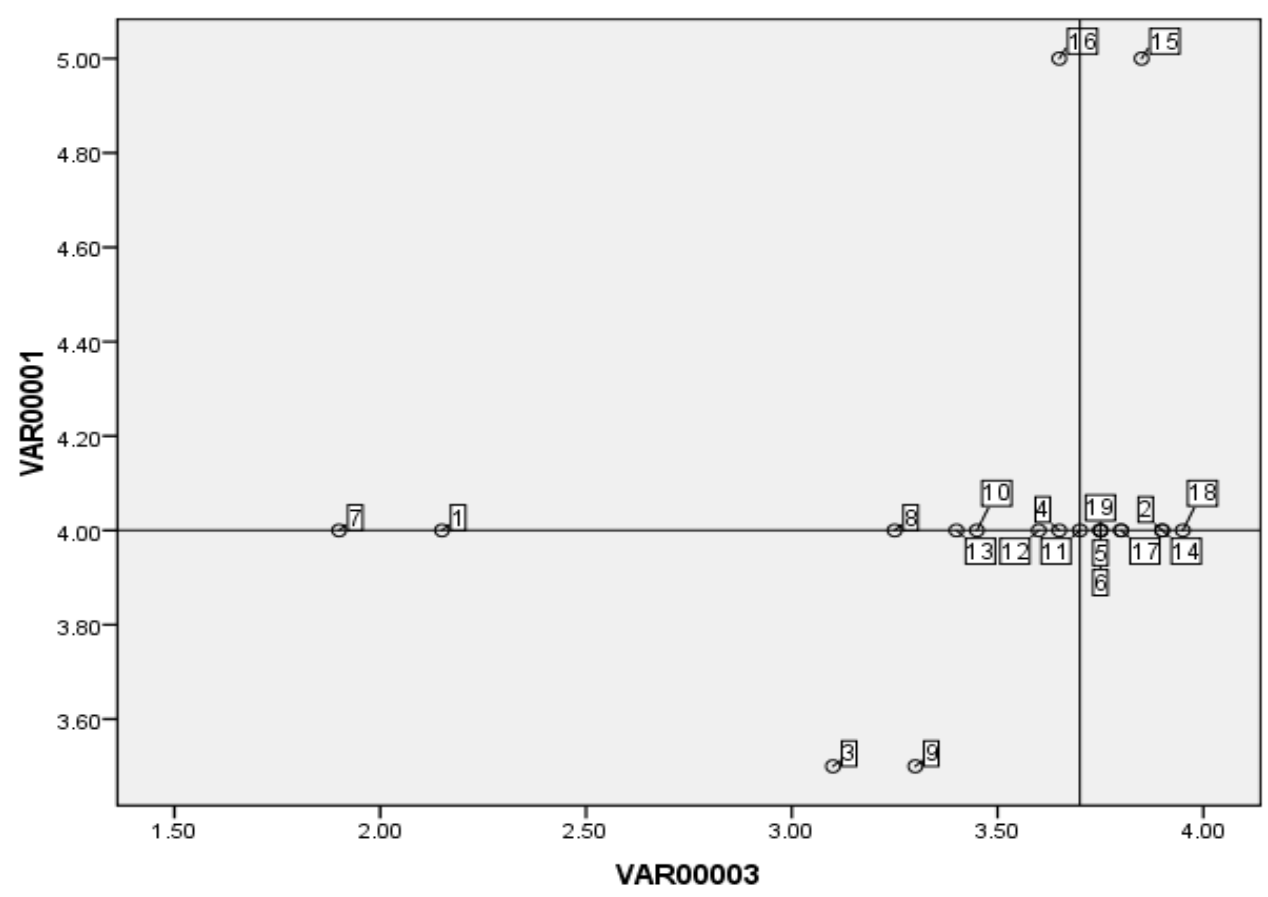

Gambar 4. Diagram Kartesius Pengukuran Kepuasan Pelanggan

Dari gambar 4 diatas maka dapat di interpretasikan sebagai berikut

1. Kuadran A

Kuadran A menunjukan faktor atau atribut yang dianggap penting oleh wisatawan namun kondisi pada saat ini belum memuaskan, variable variable yang termasuk dalam kuadran ini adalah

(7) Wisatawan paham dengan rute perjalanan di dalam kawasan Taman Sari

(8) Petugas Taman Sari ramah kepada wisatawan

(1) Penempatan ATM mudah dijangkau oleh wisatawan

(4) Tersedianya papan informasi yang cukup untuk memberi informasi kepada wisatawan

(10) Lingkungan Taman Sari bersih

(16) Wisatawan puas dengan kualitas pelayanan di Taman Sari

Dengan demikian item ini menjadi skala prioritas yang harus di benahi oleh pengelola sebab item ini sangat penting bagi para wisatawan di Taman Sari

2. Kuadran B

Kuadran B menunjukan faktor atau atribut yang dianggap penting dan memuaskan wisatawan yang sudah dilaksanakan dengan baik oleh pengelola sehingga pihak manajemen Taman Sari berkewajiban memastikan bahwa kinerja yang dilakukan oleh para petugas/pengelola dapat terus mempertahankan prestasi yang sudah dicapai

Variable variable yang termasuk dalam kuadran ini adalah

(15) Akses menuju taman sari sudah sangat mudah

(19) Pengelola telah mengembangkan nilai kebudayaan yang ada di taman sari

(18) Pengelola telah menjaga nilai kebudayaan yang ada di taman sari

(2) Lahan parkir yang disediakan pihak Taman Sari sudah cukup luas

3. Kuadran $\mathrm{C}$ 
Kuadran C menunjukan faktor yang dianggap kurang penting oleh pengelola dan tidak terlaksana dengan baik oleh pengelola

(13) Penanganan sampah dan kebersihan di Taman Sari sudah sangat baik

(12) Pemeliharaan

kawasan

Taman Sari sudah dilakukan dengan baik

(11) Petugas

mampu

berkomunikasi yang baik dengan pengunjung.

(9) Petugas Taman sari dapat menindaklanjuti keluhan dari wisatawan dengan cepat dan baik

\section{KESIMPULAN DAN SARAN}

Berdasarkan hasil perhitungan skor kepuasan pelanggan dan dengan importance performance analysis maka dapat simpulkan:

Kinerja dari pengelola taman sari dalam memberikan kualitas pelayanan kepada wisatawan sudah baik diantaranya melayani wisatawan yang datang ke loket karcis dengan baik, memberikan parker yang luas dan aman bagi wisatawan, kemudian meberikan guide yang berkualitas dengan melakukan pelatihan dan evaluasi secara berkala dan terdapat kerjasama yang baik antara sesama petugas dan juga kepada masyarakat setempat yang ada di sekitar objek wisata taman sari dan juga dukungan dari pemerintah.

Akan tetapi ada juga beberapa hal yang harus dibenahi dan di evaluasi oleh petugas dan pengelola objek wisata taman sari diantaranya dalam hal keramahtamaan, pengelola dapat meberikan rasa aman dan nyaman kepada
(3) Keamanan wisatawan sudah terjamin selama mengunjungi Taman Sari

4. Kuadran D

Kuadran ini menunjukan faktor atau atribut yang dianggap kurang penting wisatawan namun dilakukan berlebihan oleh pengelola/petugas Taman Sari

(5) PKL di Taman Sari sudah sangat mudah

(14) Wisatawan nyaman dan dapat menikmati objek wisata taman sari (17) Wisatawan puas dengan fasilitas dari di Taman Sari

(6) Ketersediaan pemandu wisata sudah cukup memadai

wisatawan yang ada di taman sari juga kebersihan kawasan taman sari yang kita amati bahwa sangat sedikit keberadaan tempat sampah di Taman Sari, pengelola juga dapat menyediakan papan informasi yang cukup dan menarik agar para wisatawan dapat mengetahui informasi seputar objek wisata budaya taman sari,

Pengelola dapat memberikan kemudahan bagi wisatawan yang ingin mengambil uang di Atm, , karena wisatawan dapat lebih puas dan nyaman apabila Atm berada dekat dengan lokasi wisata taman sari, kurangnya penunjuk jalan atau rute yang di harus di tempuh selama di kawasan taman sari, membuat wisatawan bingung dan tersesat sehingga wisatawan tidak puas dan juga wisatawan tidak dapat mengunjungi seluruh area wisata taman sari, dan juga memberikan guide yang cukup serta memberikan pelatihan serta evaluasi kepada petugas di taman sari, pengelola dituntuk untuk mampu menjaga nilai budaya dari wisata taman sari. 
Bounda, Greg, et al (1994), Beyond Total Quality Management : Toward the Emerging Paradigm. New York: McGraw-Hill, Inc.

Crosby, Philip B.(1996), Quality is Free: The Art of Making Quality Certain. New York: McGraw-Hill Book Co.

Garvin, David A. (1983), “ Quality on the Line”, Harvad Business Review, Sept-Oct, pp.6475

International Organization for Standarizasion (IOS) dalam Kurniawaty (2012)

Martilla dan James pada tahun 1977 dalam artikel mereka "Importance-Performance Analysis" yang dipublikasikan di Journal of Marketing.

Rensis, Likert. 1932. "A Technique for the measurement of attitudes", Jurnal Psikologi, 140(55): hal. 1-55

Sugiyono, (2010). StatistikaUntuk Penelitian. Bandung : Alfabeta,CV.

Sugiyono, (2012). MetodePenelitian Kuantitatif Kualitatif dan R\&D. Bandung : Alfabeta, CV

Sutopo. 2006. Metodologi Penelitian Kualitatif. Surakarta: UNS

TJIPTONO, Fandy dan Anastasia Diana (2000), Total Quality Management, Edisi II. Yogyakarta: Penerbit Andi Offset

Uyanto, Stanislaus S, (2009).Pedoman Analisis Data Dengan SPSS.Yogyakarta: Griya Ilmu. 